УДК 619.614.48:616.98:579.873.21

(C) 2012

Палий А. П., кандидат ветеринарных наук

Национальный научный центр

«Институт экспериментальной и клинической ветеринарной медицины»

\title{
ИЗУЧЕНИЕ РЕЗИСТЕНТНОСТИ АТИПИЧНЫХ МИКОБАКТЕРИЙ ОТНОСИТЕЛЬНО ДЕЗИНФЕКТАНТА «ЭКОЦИД С»
}

\section{Рецензент - кандидат ветеринарных наук И. Н. Дегтярёв}

\begin{abstract}
Наведені результати досліджень резистентності атипових мікобактерій I, II, III і IV груп за класифікаиією Раніона до бактерицицної дії дезинфікуючого препарату «Екочид С». У результаті проведених досліджень встановлено, щуо атипові мікобактерії, що відносяться до однієї і тієї ж групи за Раніоном, мають різний рівень резистентності до дії одного і того ж дезинфектанта. Найбільи стійкою культурою щуодо препарату «Екоичид C» є M. fortuitum, а наймени стійкістю володіють культури атипових мікобактерій видів M. gordonae, M. flavescens, M. triviale.
\end{abstract}

Ключевые слова: бактерицидное действие, бактериостатическое действие, атипичные микобактерии, дезинфицирующчии препарат, концентрация, экспозищия.

Постановка проблемы. Мониторинг выделяемости культур микобактерий из патологического материала от реагировавших на внутрикожное введение ППД-туберкулина для млекопитающих животных и из объектов ветеринарного надзора свидетельствует о том, что рядом с возбудителем туберкулёза Mycobacterium bovis часто удаётся идентифицировать культуры атипичных микобактерий, роль которых в эпизоотическом туберкулёзном процессе на данный момент до конца не выяснена.

Анализ основных исследований и публикаций по данной проблеме. Большинство авторов относят атипичные микобактерии к самостоятельным видам рода Mycobacterium и классифицируют их согласно Раниона (1959) с учётом пигментообразования и скорости роста на питательных средах [6].

Атипичные микобактерии широко распространены в природе и большая их часть свободно размножается в природных условиях и часто является причиной сенсибилизации сельскохозяйственных животных к туберкулину, тем самым снижая диагностическую ценность туберкулиновой пробы $[1,2]$.

Для прижизненной дифференциации параллергических реакций у крупного рогатого скота от специфических, непосредственно на производстве используют симультанную пробу с применением как ППД-туберкулина, так и аллергена из атипичных микобактерий (ААМ). Однако относительно эффективности симультанной пробы единого мнения нет, и в настоящее время проводятся исследования по повышению её специфичности [5].

Детальное изучение культур микобактерий имеет особенно большое значение при решении эпизоотологических вопросов [3]. Уничтожение атипичных микобактерий в окружающей среде высокоэффективными дезинфектантами является основным способом профилактики микобактериозов животных, однако вопрос резистентности данных микроорганизмов относительно дезсредств изучен недостаточно.

Цель работы. Изучить уровень резистентности атипичных микобактерий в сравнительном аспекте относительно бактерицидных свойств нового дезинфицирующего препарата «Экоцид С».

Материалы и методы исследований. В опытах был использован дезинфицирующий препарат «Экоцид С» производства КРКА (Словения), активнодействующим веществом которого является калия пероксомоно-сульфат. Препарат апробировали в концентрации $1 \%, 3$ \%, 5 \% при экспозиции 1, 5, 24 часа относительно атипичных микобактерий M. kansasii, M. gordonae, M scrofulaceum, $\quad M$. intracellulare, $M$. terrae, M. triviale, M.xenopi, M. diernhoferi, M.flavescens, M.fortuitum, M.phlei, M. smegmatis, M. thamnopheos, которые имели характерные культуральные свойства.

Опыты были проведены согласно действующих методологий [4].

Результаты исследований. Результаты проведенных исследований представлены в таблице.

При анализе результатов, представленных в таблице, видно, что наибольшей резистентностью, в сравнении с другими микобактериями, относительно дезинфектанта «Экоцид С» обладает M. fortuitum. 
Резистентность микобактерий относительно препарата «Экоцид С»

\begin{tabular}{|c|c|c|c|c|}
\hline \multirow{2}{*}{ Культура } & \multirow{2}{*}{$\begin{array}{c}\text { Экспозиция, } \\
\text { час. }\end{array}$} & \multicolumn{3}{|c|}{ Концентрация } \\
\hline & & $1 \%$ & $3 \%$ & $5 \%$ \\
\hline \multirow{3}{*}{$\begin{array}{l}\text { M. kansasii } \\
\text { I гр. }\end{array}$} & 1 & + & + & + \\
\hline & 5 & + & + & + \\
\hline & 24 & - & - & - \\
\hline \multirow{3}{*}{$\begin{array}{l}\text { M. gordonae } \\
\text { II гр. }\end{array}$} & 1 & + & + & - \\
\hline & 5 & + & - & - \\
\hline & 24 & - & - & - \\
\hline \multirow{3}{*}{$\begin{array}{l}\text { M. scrofulaceum } \\
\text { II гр. }\end{array}$} & 1 & + & + & + \\
\hline & 5 & + & + & - \\
\hline & 24 & - & - & - \\
\hline \multirow{3}{*}{$\begin{array}{l}\text { M. intracellulare } \\
\text { III гр. }\end{array}$} & 1 & + & + & + \\
\hline & 5 & + & + & + \\
\hline & 24 & + & - & - \\
\hline \multirow{3}{*}{$\begin{array}{l}\text { M. terrae } \\
\text { III гр. }\end{array}$} & 1 & + & + & + \\
\hline & 5 & + & + & + \\
\hline & 24 & + & - & - \\
\hline \multirow{3}{*}{$\begin{array}{l}\text { M. triviale } \\
\text { III гр. }\end{array}$} & 1 & + & + & - \\
\hline & 5 & + & + & - \\
\hline & 24 & - & - & - \\
\hline \multirow{3}{*}{$\begin{array}{l}\text { M. xenopi } \\
\text { III гр. }\end{array}$} & 1 & + & + & + \\
\hline & 5 & + & + & - \\
\hline & 24 & - & - & - \\
\hline \multirow{3}{*}{$\begin{array}{l}\text { M. diernhoferi } \\
\text { IV гр. }\end{array}$} & 1 & + & + & + \\
\hline & 5 & + & + & + \\
\hline & 24 & - & - & - \\
\hline \multirow{3}{*}{$\begin{array}{l}\text { M. flavescens } \\
\text { IV гр. }\end{array}$} & 1 & + & + & - \\
\hline & 5 & + & + & - \\
\hline & 24 & - & - & - \\
\hline \multirow{3}{*}{$\begin{array}{l}\text { M. fortuitum } \\
\text { IV гр. }\end{array}$} & 1 & + & + & + \\
\hline & 5 & + & + & + \\
\hline & 24 & + & + & - \\
\hline \multirow{3}{*}{$\begin{array}{l}\text { M. phlei } \\
\text { IV гр. }\end{array}$} & 1 & + & + & + \\
\hline & 5 & + & + & + \\
\hline & 24 & + & - & - \\
\hline \multirow{3}{*}{$\begin{array}{l}\text { M. smegmatis } \\
\text { IV гр. }\end{array}$} & 1 & + & + & + \\
\hline & 5 & + & + & - \\
\hline & 24 & + & - & - \\
\hline \multirow{3}{*}{$\begin{array}{l}\text { M. thamnopheos } \\
\text { IV гр. }\end{array}$} & 1 & + & + & + \\
\hline & 5 & + & + & - \\
\hline & 24 & + & - & - \\
\hline
\end{tabular}

Примечание: «-»- отсутствие роста колоний микобактерий; «+»- наличие роста колоний микобактерий.

Одинаковый уровень устойчивости установлен у культур M. intracellulare, M. terrae, M. phlei, а также у M. smegmatis и M. thamnopheos; M. kansasii и M. diernhoferi; M. scrofulaceum и M.xenopi; M. trivial и M. flavescens. Наименее устойчивой выявилась культура M. gordonae.
Дезинфектант «Экоцид С» инактивирует $M$. fortuitum в концентрации 5\% при экспозиции 24 часа, M. intracellulare, M. terrae, M. phlei - в концентрации 3-5\% за 24 часа, M. smegmatis и M. thamnopheos - в концентрации $3 \%$ за 24 часа и в концентрации $5 \%$ при действии в течении 524 часов. 
Культуры микобактерий $M$. kansasii, M. diernhoferi утрачивали жизнеспособность при действии препарата «Экоцид С» в концентрации $1-5 \%$ при экспозиции 24 часа, M. scrofulaceum и M. xenopi - в концентрации $1 \%$ за 24 часа и $5 \%$ - при экспозиции 5-24 часа, M. triviale, M. flavescens - в концентрации $1 \%$ при экспозиции 24 часа и при $5 \%$ - за 1-24 часа.

Рост тест-культуры $M$. gordonae отсутствовал при действии препарата в концентрации $1 \%$ при экспозиции 24 часа, в концентрации $3 \%$ - за 5 часов и при $5 \%$ - за 1-24 часа.

Выводы: 1. Атипичные микобактерии, относящиеся к одной и той же группе по Раниону, имеют разный уровень резистентности к дейст-

\section{БИБЛИОГРАФИЯ}

1. Завгородний А. И. Виды микобактерий и их эпизоотологическое значение для крупного рогатого скота [Текст] / А. И. Завгородний // Вет. медицина: міжвід. темат. наук. зб. - Х., 2000. Вип. 78, Т. 1. - С. 108-113.

2. Красников Г. Патогенність атипових мікобактерій та мікобактеріози [Текст] / Г. Красников // Вет. медицина України. - 1997. - № 7. - С. 28-29.

3. Мартма O. В. Современное состояние проблемы атипичных микобактерий в ветеринарии [Текст] / О. В. Мартма // Ветеринария. - 1982. № 5. - C. 22-24.

4. Методичні рекомендації «Визначення бактерицидних властивостей дезінфікуючих засобів, вию одного и того же дезинфектанта.

2. Наиболее устойчивой культурой относительно бактерицидного действия препарата «Экоцид С» является M. fortuitum, что подтверждает целесообразность её применения как тесткультуры при первичном определении туберкулоцидных свойств новых дезинфицирующих препаратов.

3. Высокой устойчивостью к дезинфектанту «Экоцид С» обладают также M. intracellulare, M. terrae, M. phlei.

4. Наименьшей устойчивостью к дезсредству «Экоцид С» обладают культуры атипичных микобактерий видов M. gordonae, M. flavescens, M. triviale.

проведення дезінфекції та контроль їі якості при туберкульозі сільськогосподарських тварин [Текст] / А. І. Завгородній, Н. В. Калашник [та ін.] // Затв. Держ. комітетом вет. мед. України 20.12.2007 p.

5. Прокопьева Н. И. Изучение природы аллергических реакций у крупного рогатого скота благополучных по туберкулёзу стад [Текст] / Н. И. Прокопьева // Ветеринарная патология. 2004. - № 1-2. - С. 134-136.

6. Туберкулёз животных и меры борьбы с ним [Текст] / Под ред. Ю. Я. Кассича. - К.: Урожай, 1990. $-303 \mathrm{c}$. 